\title{
MIC GLOSAR DE TERMENI GEOLOGICI UTILIZAȚI ÎN STUDIUL CERAMICII ARHEOLOGICE
}

\author{
Corina Ionescu, Lucreția Ghergari
}

afloriment. V. Ocurență.

alterare. Proces complex, geologicmineralogic-chimic-fizic, prin care mineralele şi rocile se transformă sub acțiunea factorilor fizici, chimici şi biologici, în minerale noi sau asociații noi de minerale, care conțin apă, ioni hidroxilici, ioni sulfaţi etc.

analiza granulometrică. Stabilirea cantitativă a compoziției granulometrice a unei substanțe sau a unui produs, respectiv determinarea distribuției particolelor componente în categorii sau clase de o anumită mărime.

andezit. Rocă vulcanică, corespondentul de suprafață al dioritului. Are culori diverse, în general deschise: cenuşii, cenuşii-rozacee, adesea cu aspect pestriț. Din punct de vedere chimic este o rocă intermediară, având un conţinut de $\mathrm{SiO}_{2}$ între 55 şi $63 \%$ (v. Rocă magmatică).

anizotropie. Caracteristică a mineralelor (substanțelor) cristalizate de a prezenta variația unor proprietăţi fizice, inclusiv cele optice, în funcție de direcție. Mineralele cristalizate în sistemul cubic nu prezintă anizotropie, ele fiind izotrope (v. Izotropie).

angobă. Masă ceramică obținută dintr-o suspensie fină de argilă rezultată prin decantare, care serveşte la acoperirea cu un strat subțire, a produselor ceramice înainte de ardere, pentru a le masca culoarea naturală sau pentru a acoperi unele defecte, neregularităţi ale suprafeței. Grosimea stratului de angobă este de la câțiva zeci de microni la $1 \mathrm{~mm}$ sau chiar mai mult. V. Barbotină.

arenit. Categorie granulometrică ce include particule (granule) cu diametrul cuprins între 0,063 şi $2 \mathrm{~mm}$. V. Analiza granulometrică. Sinonim: Psamit.

argilă. Rocă sedimentară fin-granulară, în majoritate formată din particule sub 0,004 mm diametru. Este în general stratificată iar din punct de vedere mineralogic este constituită dintr-un amestec de minerale argiloase (de tipul caolinitului, illitului şi altele) la care se adaugă cantităţi variabile de cuarț, mice, uneori carbonaţi (calcit sau/şi dolomit, sub 10\%), oxizi-hidroxizi de fier şi alte minerale. Constituie materia primă pentru obținerea ceramicii tradiţionale.

argilă oligomictică. Argilă constituită predominant dintr-un singur tip (specie) de mineral argilos. Exemple: argilă caolinitică (constituită majoritar din caolinit), argilă illitică (constituită din illit).

argilă polimictică. Argilă constituită din mai multe tipuri de minerale argiloase. Exemple: argilă caolinitică-illitică etc.

bazalt. Rocă vulcanică bazică, cu structură porfirică, fin granulară, compactă, de culoare neagră, formată prin consolidarea lavei. Conţinutul de $\mathrm{SiO}_{2}$ în compoziţia bazaltelor este relativ scăzut (între 45 şi 52\%). Este corespondentul de suprafață al gabbroului. S-a utilizat în epocile preistorice şi în antichitate la confecționarea râşnițelor.

bioclast. Fragment de organism care poate apare în compoziţia ceramicii şi care provine fie din materia primă (organism fosil) fie este adăugat ca degresant. Exemple de bioclaste: cochilii şi valve de moluşte şi ostracode, țeste de foraminifere, radiolari şi diatomee, spiculi de spongieri şi radiolari, dar şi oase pisate de animale.

birefringență. Capacitatea unor minerale de a descompune lumina în două raze diferite. Birefringența constituie un element deosebit de important în identificarea optică a mineralelor. Mineralele birefringente apar luminoase şi diferit colorate la microscop, la nicoli în cruce.

calcar. Rocă sedimentară constituită majoritar din calcit $-\mathrm{CaCO}_{3}$. Granulele 
constituente pot fi de mici dimensiuni (calcar micritic; cristale sub $0,004 \mathrm{~mm}$ ) sau de dimensiuni mai mari (calcar sparitic; cristale peste $0,004 \mathrm{~mm})$. Calcarele se formează organogen (din organisme) sau prin precipitație. Calcarul poate conține diferite impurități: cuarț, feldspați, mice, minerale argiloase etc.

calciclaste. Pot fi: 1 - Litoclaste (fragmente) de roci carbonatice, cum sunt calcarele, dolomitele; 2 - Cristaloclaste (fragmente de cristale) de carbonați; 3 Bioclaste (fragmente de organisme) constituite $\operatorname{din} \mathrm{CaCO}_{3}$.

calcit. Mineral cu compoziţia $\mathrm{CaCO}_{3}$ (carbonat de calciu), de culoare albă, crem sau galben, brun, roz, verde, negru, în funcție de impuritățile conținute. Calcitul este componentul mineralogic principal al calcarelor şi marmurelor. În arheometrie calcitul constituie unul din mineralele indicatoare ale temperaturii la care a fost arsă ceramica. Agregatele macrocristaline de calcit se descompun mai greu şi la temperatură mai ridicată (peste $900^{\circ} \mathrm{C}$ ) decât agregatele microcristaline, care se descompun în gneral începând cu $\quad 800-850^{\circ} \mathrm{C}$. Intensitatea descompunerii calcitului din ceramică este şi funcție de timpul de ardere, o ardere mai lungă favorizând descompunerea avansată. Calcitul este prezent în ceramică atât sub formă primară, originar din materiile prime cât şi sub formă secundară, ca rezultat al îngropării cioburilor ceramice în sol.

caolinit. Mineral argilos (alumosilicat cu conținut de $\mathrm{OH}^{-}$), având formula $\mathrm{Al}_{4}\left[\mathrm{Si}_{4} \mathrm{O}_{10} \mathrm{l}(\mathrm{OH})_{8}\right]$ foarte fin cristalizat, de culoare albă. Constituie materia primă pentru obținerea porțelanului şi este un component principal al argilelor utilizate în ceramică. Se formează în natură prin alterarea mineralelor aluminosilicatate din unele roci.

carbonați. Grupă de minerale având ca anion radicalul $\mathrm{CO}_{3}^{2-}$ combinat $\mathrm{cu}$ diferiți cationi bivalenți: $\mathrm{Ca}, \mathrm{Mg}, \mathrm{Sr}, \mathrm{Ba}, \mathrm{Fe}, \mathrm{Mn}$ etc. Exemple de carbonați: $\mathrm{CaCO}_{3}$ - calcit, $\mathrm{CaMg}\left(\mathrm{CO}_{3}\right)_{2}$ - dolomit, $\mathrm{FeCO}_{3}$ - siderit, $\mathrm{MgCO}_{3}$ - magnezit.

categorie granulometrică de ceramică. Categorie calitativă care exprimă finețea ceramicii, pe baza clasei predominante de granule (ca dimensiuni). De exemplu, ceramica fină corespunde unei clase granulometrice lutito-siltice, cea semifină clasei lutito-siltoarenitice iar cea grosieră fracției silto-arenitolutiticee. V. Finețea ceramicii.

ceramic $\breve{a ~ f i n a ̆ . ~ C e r a m i c a ̆ ~ i ̂ n ~ c a r e ~}$ predomină clasa (categoria) granulometrică lutitică. Aspectul ciobului ceramic la suprafață şi în spărtură este foarte fin-granular, nefiind posibilă determinarea compoziției, respectiv a fazelor minerale cu ochiul liber. Conţinutul în categoria arenitică (grosieră) nu depăş̧eşte 5\%.

ceramică grosieră. Ceramică cu aspect aspru, neomogen, în care categoriile granulometrice arenit şi rudit au o participare notabilă (peste $15 \%$ ). $\mathrm{Cu}$ ochiul liber se pot observa şi recunoaşte particule grosiere, de dimensiuni mai mari de $1 \mathrm{~mm}$, adesea reprezentate de litoclaste.

ceramică semifină. Ceramică caracterizată de predominarea, în egală măsură, a categoriilor granulometrice lutit şi silt. Aspectul ciobului ceramic la suprafaţă şi în spărtură este relativ fin, dar este posibilă determinarea unor componenți minerali mai grosieri vizibili cu lupa (mărire $5 \mathrm{x}$ ) sau chiar cu ochiul liber. Conținutul în categoria arenitică + ruditică este de $5-15 \%$.

ceramoclast. Fragment de ceramică de dimensiuni mici, introdus intenționat în pasta ceramică ca degresant. Sinonim: ciob pisat, ciob ceramic, şamotă.

clast. Granulă sau fragment individual de cristal, rocă, rest organic (valvă, cochilie, schelet), ceramică.

component neplastic. Constituent al ceramicii, cu caracteristici neplastice, ex. degresanţ̦ii: cuarț, feldspat, litoclaste diverse etc.

compoziție fazală. Ansamblul de compuşi cristalini sau amorfi.

compoziție fazală a ceramicii. Asociaţia de minerale şi compuşi vitroşi, respectiv faze minerale, care constituie corpul ceramic.

coroană de reacție. Zona în care au loc schimburi de substanță între două minerale sau asociații de minerale diferite geochimic, care se găsesc la un anumit moment în condiții termodinamice de instabilitate. În ceramică apar 
coroane de reacție la limita dintre unele claste şi matricea argiloasă.

cristal. Produs natural sau sintetic ale cărui particule componente sunt dispuse spațial în nodurile unei rețele reticulare. Rețeaua cristalină a unui mineral are o simetrie bine determinată şi este omogenă din punct de vedere chimic şi fizic.

cristalin. Se referă atât la masele respectiv produsele cristalizate cât şi la formațiunile geologice metamorfozate (formațiuni cristaline).

cristalizare. Formarea (creşterea) cristalelor din topituri, lichide, soluții sau gaze (sublimare).

cristaloclast. Fragment de monocristal.

cuarțit. Rocă metamorfică constituită majoritar din cuarț. Rezultă prin metamorfozarea gresiilor şi conglomeratelor cuarțoase. Se utilizează la confecționarea uneltelor litice.

dacit. Rocă vulcanică fin-granulară, de compoziție acidă. Macroscopic, are aspect pestriț. Structura rocii este porfirică, adică este constituită din cristale mari (numite fenocristale) şi o masă fundamentală microcristalină sau microcristalină-vitroasă (conține sticlă).

degresant. Material fin granular, neplastic, prezent în materia primă (degresant natural) sau adăugat intenționat în pasta ceramică (degresant artificial) în scopul scăderii plasticității, respectiv obținerii unei consistențe care să permită modelarea. Degresantul are rol şi în procesul de uscare şi ardere, prin diminuarea intensității contracției, prin creşterea tăriei/consistenței ciobului ars, prin creşterea rezistenței acestuia la şocuri termice (Shepard, 1976; Velde \& Druc, 1999) Ca degresanți artificiali se folosesc materii sau materiale anorganice şi organice, cum sunt ceramică pisată, fragmente de roci vulcanice (tufuri vulcanice, cenuşă vulcanică, piatră ponce), metamorfice (gnaise, amfibolite, diverse şisturi) şi sedimentare (calcare, cretă, nisipuri, gresii slab cimentate), respectiv resturi vegetale (pleavă, semințe, paie), scoici, oase de animale sau chiar resturi de țesături/fibre textile (Shepard, 1976). difractometrie de raze $X$, metoda pulberii. Procedeu fizic de analiză structurală utilizat în determinări calitative şi cantitative ale fazelor cristalizate, respectiv a mineralelor. Este un procedeu distructiv de analiză.

difractometru de raze $X$. Echipament pentru obținerea difractogramelor de raze $\mathrm{X}$.

difuzie. Deplasarea ionilor, atomilor sau a moleculelor într-un mediu gazos, lichid sau solid sub influența unui gradient de concentrație (zone cu concentrații diferite). Ex. difuzia $\mathrm{Fe}$ dinspre matrice spre clastele de cuarț, în ceramica arsă la temperaturi ridicate (peste 900 $\left.950^{\circ} \mathrm{C}\right)$.

diorit. Rocă magmatică intruzivă, neutră din punct de vedere al chimismului, cu structură granulară. Conținutul maxim de cuarț este de $5 \%$ iar feldspații plagioclazi sunt reprezentați de termeni bogați în calciu.

enclavă. V. Xenolit.

feldspați. Aluminosilicați de potasiu $\mathrm{K}$ (feldspați potasici) sau sodo-calcici (feldspați plagioclazi), feldspații sunt constituenți comuni ai rocilor magmatice, metamorfice şi în mai mică măsură a celor sedimentare. Cei mai frecvenți feldspați sunt: plagioclazii, ortoclazul, microclinul. Feldspații din ceramică pot fi minerale termoindicatoare pentru temperaturi ridicate, de peste $850^{\circ} \mathrm{C}$, exprimate prin fenomene diferite: devin parțial izotropi, încep să se topească etc.

faz̆a minerală. Compus cu formulă chimică bine definită, cu structură omogenă (cristalină sau amorfă) şi proprietăți fizice determinate.

filosilicați. Grupă structurală de minerale (silicați) cu forme de foițe, lamele, solzi (ex. micele, mineralele argiloase).

finețea ceramicii. Clasificarea ceramicii pe baza compoziției granulometrice. Ghergari et al. (1999), Ionescu \& Ghergari (2002), Ionescu \& Ghergari (2004) au propus clasificarea pe baza evaluării cantității de arenit şi rudit, astfel: ceramică fină (sub 5\% fracție de dimensiuni arenitice), semifină (între 5 şi 15\% arenit) şi grosieră (peste $15 \%$ arenit). V. Granulometrie, Clasificare granulometrică.

fisură de contracție. Microfractură rezultată în ceramică în urma deshidratării unor 
minerale argiloase sau prin eliminarea peliculei de apă ce înconjoară particole neplastice.

gabbrou. Rocă magmatică intruzivă bazică, având structură cristalină caracteristică (cristale prismatice bine dezvoltate de plagioclazi şi piroxeni, orientați diferit). În general are culoare neagră.

gehlenit. Silicat de aluminiu şi calciu care se formează în ceramica cu conținut de calcit la temperaturi de peste $850^{\circ} \mathrm{C}$, la contactul dintre clastele calcitice şi matricea argiloasă. ${ }^{1}$

geoarheologie. Ştiință cu caracter interdisciplinar care aplică metode geologice la studiul siturilor arheologice în general şi al artefactelor descoperite în siturile arheologice, în special.

gnais. Rocă metamorfică constituită din cuarț, feldspați, mice la care se pot adăuga minerale care pot preciza unumite varietăți cum sunt: granații, amfibolii etc. Gnaisele se formează în condiții de temperatură şi presiune ridicate.

gol, goluri. Spații libere de tipul fisurilor, porilor care apar în corpul ceramic,. Apariția golurilor se datorează mai multor cauze, printre care se numărără descompunerea termică a unor minerale, reacții chimice cu formare de minerale noi, contracții de uscare-ardere, tehnica de modelare, stratificația inițială a rocii argiloase. V. Pori.

granit. Rocă magmatică acidă, consolidată în adâncimea scoarței terestre. Are structură granulară şi un conţinut de feldspat potasic între 35 şi $90 \%$ din totalul feldspatului.

granodiorit. Rocă magmatică acidă, formată în adâncime, cu structură granulară şi un conținut de feldspat potasic între 10 şi $35 \%$ din totalul feldspatului.

granulometrie. V. Analiza granulometrică, Finețea ceramicii.

gresie. Rocă sedimentară compactă, constituită din arenit (nisip) cimentat.

grupa mineralelor argiloase. Grupă de minerale filosilicatate de tip caolinit, talc, illit. V. Filosilicați.

\footnotetext{
${ }^{1}$ Antonelli et al., 2002; Kacim \& Hajjaji, 2003; date personale experimentale
}

hartă geologică. Transpunerea pe harta topografică a formațiunilor geologice care se găsesc sub pătura de sol. Hărțile geologice pot să redea litologia formațiunilor (de obicei prin semne) cât şi vârsta acestora (redată prin culori).

hematit. Oxid de fier cu formula $\mathrm{Fe}_{2} \mathrm{O}_{3}$. $\mathrm{Nu}$ are proprietăți magnetice. Are culoare neagră până la cenuşie. Este constituent important al matricei ceramicii, în care se formează începând cu $300^{\circ} \mathrm{C}$ (Gualtieri \& Venturelli, 1999). Este mineralul care dă culoarea roşie intensă ceramicii arse în atmosferă oxidantă.

illit. Mineral argilos, constituent principal al argilelor, format prin hidratarea micelor, parțial fuzibil, utilizat pentru obținerea ceramicii. Este un alumosilicat de potasiu cu conținut de $\mathrm{OH}^{-}$.

indice de refracție. Mărime fizică referitoare la refracția luminii în medii cu densități diferite, caracteristică mineralelor (substanțelor solide). Reprezintă un indicator optic important în identificarea mineralor la microscopul petrografic.

intensitatea de ardere a ceramicii. Evaluare empirică a condițiilor de ardere a ceramicii arheologice, pe baza rezistenței mecanice a ciobului ceramic. Poate fi intensitate de nivel scăzut (ciobul are consistență redusă, se poate zgâria cu unghia), de nivel mediu (ciobul ceramic este relativ rezistent, dur, se zgîrie cu un ciob de sticlă, cu o lamă de fier) şi de nivel ridicat (ceramică arsă la temperaturi ridicate, cu un avansat grad de vitrifiere, cu duritate ridicată şi care se zgârie numai cu o lamă de oțel).

intensitatea proceselor de vitrifiere. Mărime exprimată prin cantitatea de sticlă rezultată în urma tratamentului termic, respectiv a topirii matricii argiloase.

izotrop. Caracteristică a unor materiale care prezintă proprietățile fizice vectoriale constante în toate direcțiile spațiului. De ex. propagarea luminii prin minerale amorfe şi cristalizate în sistemul cubic se face cu aceeaşi viteză în toate direcțiile, ele reprezeneând medii izotrope. La microscopul petrografic, la nicoli în cruce, mineralele izotrope rămân întunecate (negre). 
linia bazală. Pe difractograma unui mineral argilos, linia bazală corespunde liniei de difractie cu valoarea cea mai mare. Linia bazală are o importanță foarte mare în procedura de stabilire a transformărilor termice suferite de mineralele argiloase în timpul arderii ceramicii, respectiv în determinarea temperaturii de ardere. Exemple de linii bazale redate prin valorile $\mathrm{d}$ (distanța dintre două plane reticulare): caolinit $\sim 7 \AA$, illit $\sim 10 \AA$, Camontmorillonit $\sim 15 \AA$, Na-montmorillonit $12 \AA$, clorit $\sim 14 \AA$. Sunt importante nu numai pentru evaluarea temperaturii de ardere dar şi pentru identificarea materiei prime argiloase folosite.

linie de difracție. Semnal obținut prin difractia razelor $\mathrm{X}$ ce cad pe plane reticulare cu aceeaşi orientare. Pe difractogramă liniile de difracție apar ca picuri orientate în sus.

litoclast. Fragment de rocă, prezent adesea în masa ceramică, unde poate constitui un indicator al materiei prime utilizate.

lumină polarizată. Este lumina care vibrează într-un singur plan. Se obține la trecerea luminii obişnuite (care vibrează în toate direcțiile) printr-o placă polarizoare sau printr-un nicol.

lupă. Instrument constituit dintr-o lentilă, utilizat la mărirea imaginii.

lupă stereoscopică. Sinonim: binocular

lutit. 1 - Categorie granulometrică ce cuprinde particule cu diametrul mai mic de 4 $\mu \mathrm{m} \quad(0,004 \mathrm{~mm})$, cum sunt de exemplu mineralele argiloase. 2 - Rocă sau sediment constituit din particule foarte fine, în general de minerale argiloase. Argila este un lutit. Sin. Argilă.

matrice. Component principal al ceramicii, reprezentat de masa de minerale argiloase sinterizate sau vitrifiate, în care se află diferite claste.

micaşist. Rocă metamorfică cu textură şistoasă, constituită din cuarț, mice (muscovit şi biotit) la care se pot adăuga: feldspați (sub $20 \%$ ), granați etc.

mice. Minerale comune (filosilicați) rocilor magmatice, metamorfice şi sedimentare, cu aspect lamelar-foios. Cele mai comune mice sunt biotitul, muscovitul şi cloritul. microcristalin. Masă constituită din cristale mici observabile microscopic.

microcristalin-amorfă (despre matrice, pastă). Structură a masei argiloase sinterizate şi parțial vitrifiate, în care se păstrează încă componenți cristalini (în afara cristaloclastelor şi/sau litoclastelor).

microscop petrografic. Utilizează lumină polarizată prin transmisie. Se foloseşte la studiul mineralor şi rocilor, preparate sub formă de secțiuni subțiri.

minerale argiloase. Componenții principali ai argilelor cu structură de filosilicați şi cristale de dimensiuni micronice (obişnuit $<2 \mu \mathrm{m})$. V. filosilicaţi şi grupa mineralelor argiloase.

minerale termoindicatoare. Minerale utilizate la stabilirea unor temperaturi pe baza transformărilor ireversibile suferite la $\mathrm{o}$ încălzire anterioară. Schimbările din structura şi compoziția chimică a unui mineral termoindicator sunt ireversibile şi au loc la temperaturi precis stabilite, astfel că efectele nu se mai obțin la o nouă încălzire (cum este analiza termică). Dintre mineralele termoindicatoare cele mai cunoscute şi utilizate fac parte carbonaţii (calcitul, dolomitul), unele minerale argiloase (illitul, caolinitul), unii feldspați potasici. Tot minerale termoindicatoare sunt şi acele minerale care se formează în condiții bine stabilite, cum sunt gehlenitul, wollastonitul, mullitul sau anortitul din ceramică.

microfabric. Microstructura şi microtextura unei roci sau produs sintetic (ex. ceramica).

mineral. Mineralele sunt elemente native sau compuşi chimici naturali, omogeni din punct de vedere fizico-chimic şi structural, care iau naştere prin procese geologice. Mineralele au o compoziție chimică bine definită şi o structură cristalină sau amorfă specifică. In prezent se cunosc peste 3900 de specii de minerale diferite.

monocristal. Mineral format dintr-un singur cristal.

neocristale. Cristale nou formate, prin transformarea altora vechi (prin metamorfism sau alterare) sau prin aport de substanță. 
nicol. Prismă de calcit perfect transparent utilizată la microscopul petrografic pentru a produce lumină polarizată.

nisip. Produs format din cristaloclaste şi litoclaste neconsolidate care se încadrează în categoria granulometrică arenit (claste cu dimensiuni cuprinse între 0,063 şi $2 \mathrm{~mm}$ diametru). Sinonim: psamit. Din punct de vedere compozițional se cunosc nisipuri oligomictice (ex. cuarțoase) sau polimictice care pot fi constituite din diverse minerale: cuarţ, feldspați, mice etc.

ocurență. Locul de apariție la suprafața pământului a unor formațiuni geologice, respectiv roci sau/şi minereuri. Sin. Afloriment.

pastă. V. Pastă ceramică.

pastă ceramic $\breve{a}$. Amestec plastic de argilă, degresant şi apă utilizat la obținerea ceramicii.

permeabilitatea ceramicii. Proprietate a vaselor ceramice poroase de a permite circulația apei. Pentru ca un corp ceramic să fie permeabil, este necesar ca porii să nu fie izolați ci interconectați atât între ei cât şi cu suprafața. V. Porozitate.

plagioclaz. Feldspat calco-sodic cu formula $\mathrm{Ca}\left[\mathrm{Al}_{2} \mathrm{Si}_{2} \mathrm{O}_{8}\right]-\mathrm{Na}\left[\mathrm{AlSi}_{3} \mathrm{O}_{8}\right]$. Plagioclazii sunt constituenți importanți ai rocilor.

plasticitate. Proprietatea unor roci argiloase care în amestec cu apa formează mase ce se deformează plastic sub acțiunea unor forțe mecanice iar după uscare îşi păstrează forma.

pori primari. Pori rezultaţi în urma procesării obiectului ceramic (bule de gaz sau pelicule de apă rămase captive între strătulețele de material argilos. Frecvent apar în zonele de îmbinare a unor părți constituente ale obiectului (torți, ornamente, suluri, bulgări de argilă). În general aceşti pori au forme alungite, cvasilenticulare şi se dispun adesea paralel cu suprafața ciobului sau oblic față de aceasta.

pori secundari. Pori prezenți în materiale ceramice şi rezultați în urma eliminării apei sau descompunerii unor substanțe organice (resturi vegetale) sau anorganice (diferite minerale, instabile la temperaturi înalte). Cauzele apariției porilor secundari sunt fie arderea prea îndelungată, fie arderea foarte rapidă dar la temperatură ridicată. În general porii secundari au forme neregulate care trec gradat în fisuri.

porozitate. Caracteristică a unor corpuri, în special ceramică, de a conține goluri de diferite mărimi şi forme. Porozitatea ceramicii se determină fie prin estimarea ponderii golurilor observate în secțiuni subțiri, fie prin calcul (Shepard, 1976).

probă reprezentativă. Material tipic, care conține informațiile corespunzătoare materialului eşantionat. Poate fi probă mineralogică, petrografică, metalografică, pedologică (de sol).

reacție de deshidratare. Reacție chimică în timpul căreia are loc pierderea apei de constituție $\left(\mathrm{H}_{2} \mathrm{O}\right)$ ce intră în compoziția unei substanțe.

reacție de deshidroxilare. Reacție chimică în timpul căreia se pierde gruparea hidroxilică $\left(\mathrm{OH}^{-}\right)$din structura mineralelor.

recristalizare. Fenomen ce are loc în fază solidă în anumite condiții de temperatură şi presiune bine determinate. Ex. formarea agregatelor larg cristalizate din agregate microcristaline.

relict mineral. Fragment de mineral rămas netransformat în timpul desfăşurării anumitor procese (topire, recristalizare etc.)

riolit. Rocă vulcanică acidă cu structură porfirică sau fin granulară. A constituit una din materiile prime utilizate la confecționarea uneltelor litice şlefuite.

rocă. Asociație naturală mono(constituită dintr-un singur tip de mineral) sau poliminerală (constituită din minerale diferite). În funcție de geneza lor, rocile se clasifică în trei mari categorii: roci magmatice, metamorfice şi sedimentare. Exemple de roci: granitul, bazaltul, calcarul, argila, gresia, marmura.

rocă magmatică. Rocă formată prin solidificarea magmelor (în interiorul scoarței terestre) sau lavelor (la suprafața pământului sau în imediata apropiere a acesteia). Exemple: granit, diorit, andezit, bazalt (tabelul 1). Rocile magmatice se clasifică, grosso modo, în funcție de chimism, respectiv de cantitatea de $\mathrm{SiO}_{2}$, în roci ultrabazice (cu mai puțin de $45 \% \mathrm{SiO}_{2}$ ), bazice $\left(\mathrm{SiO}_{2}\right.$ între 45 şi $\left.52 \%\right)$, roci intermediare 
$\left(\mathrm{SiO}_{2}\right.$ între 52 şi $\left.63 \%\right)$ şi roci acide (cu peste $63 \% \mathrm{SiO}_{2}$ ).

rocă magmatică intruzivă. Rocă cu structură granulară, formată prin solidificarea magmelor în interiorul scoarței terestre, la diferite adâncimi. Exemple: granit, diorit, gabbrou.

rocă metamorfică. Rocă obținută în stare solidă sub acțiunea unor condiții de temperatură şi presiune determinate, prin transformarea unor roci preexistente (magmatice, sedimentare sau chiar metamorfice). Exemple: gnaise, micaşisturi, marmură, şisturi cuarțoase cu biotit, şisturi sericitoase.

rocă sedimentară. Rocă formată la suprafața terestră, prin acumularea în bazine a produselor de dezagregare-alterare a unor roci preexistente. Exemple de roci sedimentare: calcare, argile, marne, gresii, silicolite, tufuri.

rocă vulcanică. Rocă magmatică cu structură fin-granulară sau porfirică, formată prin consolidare la suprafața scoarței terestre sau în apropierea acesteia, din lave generate de activitatea vulcanică. Exemple: bazalt, andezit, riolit, obsidian, piatră ponce, tuf vulcanic.

rocă solificată. Rocă transformată parțial în sol, la contactul cu atmosfera, hidrosfera şi biosfera.

rudit. Categorie granulometrică ce cuprinde particulele cu diametrul mai mare de 2 $\mathrm{mm}$.

scoarță de alterare. Partea superficială a crustei terestre supusă proceselor de transformare sub acțiunea hidrosferei, atmosferei, biosferei şi a factorilor climatici. V. Alterare.

secțiune subțire. Preparat mineralogic realizat prin şlefuirea unei probe compacte din roci, minerale, unele soluri, ceramică, sticlă până la obținerea unei lamele de cca 0,01-0,02 mm grosime, care se fixează între o lamă şi o lamelă de sticlă cu balsam de Canada sau răşini sintetice. Se studiază la microscopul de transmisie cu lumină polarizată. Secțiunea subțire neacoperită cu lamela de sticlă se poate studia cu microsonda electronică. Pentru obținerea unei secțiuni subțiri, probele friabile se impregnează cu răşini epoxidice.

sediment. Acumularea de material clastic, chimic sau biotic rezultat din crusta de alterare prin transportul acestuia de către aer, apă, gheață.

silicați. Cel mai mare grup de minerale, care formează rocile. Ex. de silicați sunt: feldspații, amfibolii, piroxenii, micele ş.a.

siliciclaste. Litoclaste şi cristaloclaste constituite în principal din cuarț.

silicolit. Rocă sedimentară consituită din silice $\left(\mathrm{SiO}_{2}\right)$ care poate să formeze strate sau mase neregulate (accidente silicioase) în roci carbonatice, argiloase sau evaporitice. Silexul, cherturile sunt silicolite.

silt. Categorie granulometrică ce include particule cu diametrul cuprins între 0,004 şi $0,063 \mathrm{~mm}$. Sin. Aleurit.

sinterizare. Proces incipient de topire a unor materiale, în care formarea de pelicule de sticlă la limita dintre componenții cristalini se asociază cu fenomene de compactizare. Este procesul ce determină începutul transformării pastei argiloase într-un tot unitar, dur, neplastic, numit masă ceramică.

slip. Termen arheologic provenit din lb. engleză care se referă la un amestec fin de argilă şi apă utilizat pentru acoperirea suprafețelor vaselor ceramice. Sin. Angobă.

sol. Solul reprezintă partea superficială a scoarței de alterare şi este rezultatul interacțiunii roclior $\mathrm{cu}$ diferiți factori pedogenetici: climă, apă, organisme vii animale şi vegetale etc.

sticlă. Masă silicatică cu structură amorfă, rezultată din topirea şi apoi solidificarea unor materiale anorganice diverse.

stratificație. Element structural în general de formă plană, care apare în cadrul unui sediment datorită unei discontinuități în granulometria sau/şi compoziția materialului sedimentat.

structură porfirică. Structură specifică rocilor vulcanice, caracterizată prin prezența unor minerale larg cristalizate, numite fenocristale, într-o masă de bază (sau masă fundamentală) mai fin cristalizată sau vitroasă.

structură reticulară a mineralelor. Aranjarea spațială ordonată a particulelor constituente ale unui compus în nodurile unei rețele. 
structura rocilor. Caracteristică a rocilor care exprimă forma cristalelor componente, dimensiunile lor precum şi raporturile dintre fazele minerale. Pentru domeniul sedimentar, structura exprimă aranjarea spațială a constituenților unui sediment.

structură zonată. 1 - Perete ceramic alcătuit, în secțiune, din unul sau mai multe strate de culori diferite sau structuri diferite; 2 structură în benzi de diferite compoziții ale unui mineral.

şamotă. V. Ceramoclast.

şisturi. Roci metamorfice caracterizate printr-o şistuozitate bine exprimată, dată de aranjarea în plan a mineralelor lamelare, ex. mice.

textura ceramicii. Aranjament spațial al unor componenți ai ceramicii cum sunt mineralele (îndeosebi cele lamelare sau prismatice), porii, pigmenții. În general textura ceramicii se observă în secțiuni tăiate perpendicular pe grosimea peretelui ceramic. În funcție de dispunerea acestor componenți, textura poate fi: orientată (aranjament în şiruri oblice sau paralele cu suprafața ciobului), haotică sau neorientată (componenți dispuşi haotic, fără nici o orientare preferențială pe o anumită direcție), circulară (lamelele aranjate mai mult sau mai puțin circular), mixtă (cu diferite texturi întâlnite în peretele ceramic al aceluiaşi obiect).

vitrificare. Proces de topire a unor materiale (silicați), urmat de solidificare într-un material amorf, sticlos. Ceramica arheologică se consideră ca având structură vitroasă atunci când cantitatea de sticlă depăşeşte cca $20 \%$. Sin. Vitrifiere.

vopsele ceramice. Substanțe utilizate pentru pictarea vaselor ceramice. Vopselele ceramice sunt rezistente la ardere sau nerezistente la ardere. şi constituite în general pe bază de oxizi metalici. Oxizii de fier dau vopsele de culoare roşie, brună sau neagră, cei de mangan, vopsele de culoare neagră sau brună.

wollastonit. Silicat de calciu cu formula $\mathrm{CaSiO}_{3}$. Este mineral termoindicator în ceramică. Se formează în ceramică obținută din argile calcaroase, la temperaturi de peste $850^{\circ} \mathrm{C}$ (Kacim \& Hajjaji, 2003). xenolit. Fragment de rocă străină, inclus în altă rocă şi având altă origine în raport cu roca în care apare. Sin. Enclavă.

zonalitate. Variația compoziției chimice a unor minerale, exprimată prin zone ritmice cu proprietăți fizice şi optice diferite.

NOTĂ: În afara mențiunilor din text, datele cuprinse în glosarul de mai sus sunt rezultatul experienței acumulate de autori în domeniul studiului ceramicii arheologice ${ }^{2}$, dar și al consultării unor lucrări de specialitate în domeniu:

- date generale geologice: Gary et al. (1977), Allaby \& Allaby (1990), Webster Dict. (1994), Parker (1997), Anastasiu et al. (1998);

- date mineralogice: Winchell \& Winchell (1976), Ianovici et al. (1976), Mastacan \& Mastacan (1976), Strunz (1982), Putnis (1992), Klein \& Hurlbut (1999), Mandarino \& Back (2004);

- date petrografice: Le Maitre et al. (1989);

- date de cultură generală: Coteanu et al. (1975), Chioreanu et al. (1978);

- date de chimie şi despre materii ceramice: Bălănescu (1964), Teoreanu et al. (1985), Herz \& Garrison (1998), Barclay (2001);

- date geoarheologice: Rapp \& Hill (1998).

\footnotetext{
${ }^{2}$ Inclusiv experimentele cu materii prime ceramice realizate în cadrul Grantului CNCSIS 1762).
} 
Cele mai comune tipuri de roci magmatice

\begin{tabular}{|c|c|c|c|c|c|}
\hline Caracteristici & & Roci bazice & Roci & \multicolumn{2}{|c|}{ Roci acide } \\
\hline $\begin{array}{l}\text { - Se formează prin } \\
\text { consolidare la } \\
\text { suprafața terestră, din } \\
\text { topituri naturale de } \\
\text { silicați, numite lave } \\
\text { - } \quad \text { Structură fin-granulară } \\
\text { - } \\
\text { Sinonim: roci } \\
\text { vulcanice }\end{array}$ & Kimberlit & Bazalt & Andezit & Dacit & $\begin{array}{l}\text { Riolit } \\
\text { Obsidian }\end{array}$ \\
\hline $\begin{array}{ll}\text { - } & \text { Se formează prin } \\
\text { consolidare în } \\
\text { adîncime, în interiorul } \\
\text { scoarței terestre din } \\
\text { topituri naturale de } \\
\text { silicați numite magme } \\
\text { - } & \text { Structură granulară } \\
\text { - } & \text { Sinonim: roci intruzive }\end{array}$ & $\begin{array}{l}\text { Peridotit } \\
\text { Serpentinit } \\
\text { Dunit }\end{array}$ & Gabbrou & Diorit & Granodiorit & Granit \\
\hline
\end{tabular}

\section{BIBLIOGRAFIE}

Allaby, A. \& Allaby, M. (Eds.) (1990) The concise Oxford Dictionary of Earth Sciences. Oxford Univ. Press, 409 p. Oxford.

Anastasiu, N., Grigorescu, D., Mutihac, V. \& Popescu, Gh.C. (1998) Dicționar de geologie. Edit. Did. şi Ped., 347 p. Bucureşti.

Antonelli, F., Cancelliere, S. \& Lazzarini, L. (2002) Minero-petrographic characterisation of historic bricks in the Arsenale, Venice. Journal of Cultural Heritage, 3, 59-64.

Barclay, K., (2001) Scientific analysis of archaeological ceramics - A Handbook of Resources. Oxbow Books, 56 p. Oxford.

Bălănescu, G. (Coord.) (1964) Dicționar de chimie. Edit. Tehnică, 668 p. Bucureşti.

Chioreanu, A., Mâciu, M., Nicolescu, N.C., Rădulescu, Gh. \& Şuteu, V. (Eds.) (1978) Mic dicționar enciclopedic. Edit. Ştiințif. şi Encicl., 1851 p. Bucureşti.

Coteanu, O., Seche, L. \& Seche, M. (Eds.) (1975) Dicționarul explicativ al limbii române. Edit. Acad. Române, 1049 p. Bucureşti.

Gary, M., McAfee Jr, R. \& Wolf, C.L. (Eds.) (1977) Glossary of geology. American Geological Instit.ute. 857 p. Washington, D.C.

Ghergari, L. Lazarovici, Gh., Ionescu, C. \& Tămaş, T. (1999) Studii geoarheologice asupra unor artefacte ceramice din Neoliticul timpuriu din România: Stațiunea de la Lunca-Poiana Slatinii, Jud. Neamț. Angvstia, 4, 1-7. Sf. Gheorghe.

Gualtieri, A. F. \& Venturelli, P. (1999) In situ study of the goethite-hematite phase transformation by real time synchroton powder diffraction. American Mineralogist, 84, 895-904.

Herz, N. \& Garrison, E. G. (1998) Geological Metods for Archaeology. Oxford University Press. 343 p. Ianovici, V., Stiopol, V. \& Constantinescu, E. (1979) Mineralogie. Ed. Did. şi Ped., 827 p. Bucureşti.

Ionescu, C. \& Ghergari, L. (2002) Modeling and firing technology - reflected in the textural features and the mineralogy of the ceramics from Neolithic sites in Transylvania (Romania). Geol. Carpath., 53 (Sp. Iss., CD), 6 p., Bratislava. 
Ionescu, C. \& Ghergari, L. (2004) Vinča ceramics (Middle Neolithic) in Transylvania: petrographical and geoarchaeological features. In Chatzipetros, A.A. \& Pavlides, S.B. (Eds.): The Proceedings of The $5^{\text {th }}$ International Symposium on Eastern Mediterranean Geology, 2, 751-754. Thessaloniki.

Kacim, S. \& Hajjaji, M. (2003) Firing transformations of a carbonatic clay from the High-Atlas, Morocco. Clay Minerals, 38, 361-365.

Klein, C. \& Hurlbut, Jr., C.S. (after Dana, J.D.) (1999) Manual of mineralogy. John Wiley \& Sons, Inc., 681 p. New York.

Le Maitre, R.W., Bateman, P., Dudek, A., Keller, J., Lameyre, J., Le Bas, M.J., Sabine, P.A., Schmid, R., Sørensen, H., Streckeisen, A., Woolley, A.R. \& Zanettin, B. (Eds.) (1989) A classification of igneous rocks and glossary of terms. Blackwell Sci. Publ., Oxford, 129 p. London.

Mandarino, J.A. \& Back, E. (2004) Fleischer's Glossary of mineral Species 2004. The Mineral. Rec. Inc., 309 p. Tucson, Az.

Mastacan, Gh. \& Mastacan, I. (1976) Mineralogie. Ed. Tehnică, 883 p. Bucureşti.

Parker, S.P. (Ed.) (1997) McGraw-Hill Dictionary of Earth Sciences. McGraw Hill Co., 468 p. New York, N.Y.

Putnis, A. (1992) Introduction to mineral sciences. Cambridge Univ. Press, 457 p. Cambridge.

Rapp, G., Jr. \& Hill, C.L. (1998) Geoarchaeology. The earth-science approach to archaeological interpretation. Yale Univ. Press, 274 p. New Haven, London.

Shepard, A.O. (1976) Ceramics for the archaeologist. Carnegie Inst., 414 p. Washington.

Strunz, H. (1982) Mineralogische tabellen. Acad. Verl., Geest \& Portig K.-G., 621 p. Leipzig.

Teoreanu, I., Ciocea, N., Bărbulescu, A. \& Ciontea, N. (1985) Tehnologia produselor ceramice şi refractare. Edit. Tehnică, 530 p. Bucureşti.

Velde, B. \& Druc, I.C. (1999) Archaeological ceramic materials. Origin and utilization. Springer-Verlag, 299 p. Berlin Heidelberg New York.

Winchell, A.N. \& Winchell, H. (1967) Elements of optical mineralogy. An introduction to microscopic petrography. Part II. Descritpion of minerals. $5^{\text {th }}$ ed. New York, Jihn Willey \& Sons, Inc. 551 p. London, Sydney.

*** (1994) Webster's new encyclopedic dictionary. Könemann, 1787 p. Cologne. 